\title{
Commentary
}

\section{Money, Money, Money! Or Is There More to Work than the CJEU Acknowledges?} By Beryl ter Haar, Assistant Professor International and European Labour Law, Leiden University, The Netherlands By Suzanne Kali, Lecturer and Researcher, Leiden University, The Netherlands

\section{Introduction}

In Hubertus, the Court of Justice of the European Union (CJEU) addressed a German measure stipulating that "[i]f an agreement provides for the termination of the employment relationship upon reaching the normal retirement age, the parties to the employment contract may postpone the termination date by agreement during the employment relationship, including on more than one occasion if necessary." Hubertus John and his employer, Freie Hansestadt Bremen, had chosen this option once. When the employer did not agree to postpone the retirement a second time, John brought legal proceedings, asserting that a fixed-term contract based on the German provision that allowed postponement of automatic termination is contrary to European law. More particularly, as raised in the preliminary questions by the Bremen Regional Employment Court, the measure was claimed to be discriminatory (Articles 2(2) and 6(1) Directive 2000/78/EC) and an abuse of fixed-term contracts (Clause 5(1) Directive 1999/70/EC).

The CJEU concluded that automatic termination of employment at a person's retirement age is widespread and accepted in many Member States. ${ }^{1}$ As in Rosenbladt, this aspect of the measure does not exceed what is necessary to

1 CJEU of 28 February 2018, Case C-46/17 Hubertus John v. Freie Hansestadt Bremen, ECLI:EU:C:2018:131, para. 24.

(C) BERYL TER HAAR \& SUZANNE KALI, 2019 | DOI:10.1163/24056901-00502017 
achieve the objectives pursued and therefore is not contrary to EU law. ${ }^{2}$ On the contrary, the measure to postpone the retirement is a derogation to automatic termination of the employment contract, because it offers employer and employee the possibility of extending their employment relationship. That postponement can take place only when both parties agree to it is essential to the CJEU finding that the provision is not unfavorable to those at retirement age. ${ }^{3}$ Hence the CJEU found no conflict with Articles 2(2) and 6(1) of Directive $2000 / 78 /$ EC.

Regarding a possible conflict with Clause 5 of Directive 1999/70/EC, the CJEU identifies two primary issues. The first is whether the automatic retirement termination clause of the collective labor agreement (CLA) converts the indefinite term of the employment contract into a fixed term. This because the CLA clause sets a hard end date to the employment contract. The CJEU rejects this conclusion, arguing that when the employee reaches retirement age the indefinite-term contract has already served its purpose of providing stable employment. ${ }^{4}$ The second issue the cJEU identifies concerns the nature of the employment contract during the postponement period of the retirement age. The CJEU considers that postponement could be "merely the contractual postponement of the retirement age initially agreed." In other words, only one clause of the contract is altered. Because this one change entails no greater (employment) insecurity than previously, the CJEU finds no conflict with Clause 5 of Directive 1999/70/EC. ${ }^{6}$ Whether such is actually the case is up to the referring (national) court to decide. In case the referring court to the contrary concludes that the period of postponement constitutes a successive fixed-term contract, the CJEU provides the following interpretation. Because the employees are at the end of their working lives, they have no expectation of alternative forms of employment, other than a fixed term contract. ${ }^{7}$ Hence, the postponement of the retirement age is to be considered as a positive derogation of the automatic employment termination on the grounds of age. Given these arguments and the fact that none of the other terms of the employment contract change during the postponement period, the CJEU sees no reason

\footnotetext{
2 CJEU of 12 October 2010, Case C-45/o9, Gisela Rosenbladt v. Oellerking Gebäudereinigungses $\mathrm{MbH}$, ECLI:EU:C:2010:601.

3 Hubertus, para. 32 .

4 Ibid., para. 44.

5 Ibid., para. 45 .

6 Ibid., para. 46 .

7 Ibid., para. 54 .
} 
why the measure at issue in the main proceedings should be precluded by Clause 5 of Directive 1999/70/EC. ${ }^{8}$

\section{Analysis I: Age-related Termination}

On multiple occasions, the CJEU has acknowledged that automatic termination of an employment contract at retirement age is not contrary to European law on age discrimination (see Palacios de la Villa,${ }^{9}$ Age Concern,${ }^{10}$ and Rosenbladt). More generally, Member States have wide discretion in determining the objective justification and choice of measures to reach the aim strived for. ${ }^{11}$ Such is particularly the case when it concerns older workers (cf. Mangold ${ }^{12}$ and again confirmed in Hubertus ${ }^{13}$ ).

The CJEU also confirmed in Hubertus that those at retirement age depend less on income from work than younger workers do. Relatedly, the CJEU found in Rosenbladt that "the persons concerned are entitled to financial compensation by means of a replacement income in the form of a retirement pension at the end of their working life."14 In Hubertus, the CJEU concluded that the measure does not conflict with EU law "simply because that worker, ... is entitled to a retirement pension."15

The importance of an alternative source of income, like a retirement pension, is also illustrated in Georgiev ${ }^{16}$ and Fuchs and Köhler. ${ }^{17}$ In Georgiev, the CJEU concluded that obligatory retirement for university professors at the age

8 Ibid., paras. $55^{-56 .}$

9 CJEU of 16 October 2007, Case C-411/05, Félix Palacios de a Villa v. Cortefiel Servicios SA, ECLI:EU:C:2007:604.

10 CJEU of 5 March 2009, Case C-388/07, The Incorporated Trustees of the National Council on Ageing (Age Concern England) v. Secretary of State for Business, Enterprise and Regulatory Reform, ECLI:EU:C:2009:128.

11 Unlike the CJEU's position towards young workers: B.P. ter Haar, "Discrimination of Young Workers: To Be Justified or Not to Be Justified?," ILaRC 4, no. 1 (2018): 230-34, at 233.

12 CJEU of 22 November 2006, Case C-144/04, Werner Mangold v. Rüdiger Helm, ECLI:EU:C:2005:709, para. 63.

13 Hubertus, para. 25.

14 Rosenbladt, para. 43, with reference to Palacios de la Villa, para. 73

15 Hubertus, para. 57.

16 CJEU of 18 November 2010, Case C-250/o9, Vasil Ivanov Georgiev v. Tehnicheski universiteit-Sofia, filial Plovdiv, ECLI:EU:C:2010:699.

17 CJEU of 21 July 2010, Joined Cases C-159/10 and C-160/10, Gerhard Fuchs, Peter Köhler v. Land Hessen, ECLI:EU:C:2011:508. 
of sixty-eight was not contrary to EU law because the professors have access to a pension. Fuchs and Köhler asserted discrimination on the grounds of age because their requests to work after they reached statutory retirement age was denied. Again with a reference to the entitlement to a retirement pension, the CJEU found the refusal not contrary to EU law. The relevance of access to alternative income was also key in $O v$. Bio Philippe. ${ }^{18}$ The CJEU concluded that a measure excluding young persons who worked during their school holidays or university vacations from an end-of-contract payment did not conflict with EU law because such workers do not face job insecurity at the end of their contract. ${ }^{19}$ Thus, the fact that pupils and students are not as dependent on employment income as others mattered in regard to whether the pertinent French legislation was contrary to EU law.

Summarizing the above case law, the CJEU found no discrimination in $O v$. Bio Philippe, saw a measure regarding retirement age workers as advantageous to them in Hubertus, and found the measures at issue in the main proceedings to be justified by an objective aim and the measure itself appropriate and necessary to achieve that aim in Rosenbladt, Georgiev, and Fuchs and Köhler. What all these cases have in common is that the workers invoking EU law were not dependent on income of work because they had access to alternative sources of income, such as a retirement pension.

\section{Analysis II: Unlimited Consecutive Postponements}

The CJEU is clear that a retirement clause in the CLA does not alter the nature of an indefinite term contract into one of fixed term. We fully agree with this. In this part of our analysis our concern lies with what to make of the potentially unlimited postponements of retirement that the German legislation in Hubertus enables?

The CJEU concludes that postponement itself does not conflict with Clause 5 of Directive 1999/70/EC. In the first of two assessments, the CJEU considers postponement as merely a renegotiated single clause of the employment

18 CJEU of 1 October 2005, Case C-432/14, Ov. Bio Philippe Auguste SARL, ECLI:EU:C:2015:643.

$19 O$ v. Bio Philippe, para. 38. For a more elaborate discussion of this case, B.P. ter Haar, "EU Age Discrimination Law: A Curse or a Blessing for EU Youth Policy?," in EU Anti-Discrimination Law beyond Gender, edited by U. Belavusau and K. Henrard (Hart Publishing, 2018), $310-11$. 
contract. ${ }^{20}$ Its second assessment focuses on when the postponement period is considered a successive fixed-term contract which could potentially result in an abusive situation as prohibited by Clause 5 of Directive 1999/70/EC. The CJEU finds no conflict with EU law, however. In fact, it finds that the measure is a favorable derogation from the principle of automatic termination because the employee has reached the retirement age. ${ }^{21}$ An essential aspect of this measure is the fact that during the postponement period the employee is entitled to all pre-existing contractual terms, including his retirement pension. ${ }^{22}$ As for the temporary nature of the postponement the CJEU argues that these workers cannot expect anything else since by age they have reached the end of their working lives. ${ }^{23}$

\section{Work Is More than an Income}

Hubertus demonstrates again that the CJEU is very lenient in accepting measures affecting employees at retirement age. We question whether this approach is sustainable. We offer two arguments.

First, statistics on the demographic developments within the EU make it clear that the population is aging rapidly. Eurostat data indicates that demographics have changed from a healthy pyramid shape to a tulip shape, which in the (near) future will be an urn shape. ${ }^{24}$ Low levels of fertility and mortality explain the aging EU population.

One aspect of the low mortality level is simply that people age. This is one reason that among the core elements of the EU policy on financially sustainable pensions are to raise the pensionable age and to link it to gains in life expectancy, restrictions to early retirement, and (national) measures to support longer working lives. ${ }^{25}$ The measure at issue in Hubertus accords with the first and third goals. In light of the statistics on demographic developments in the EU, it is only to be expected that measures challenged in Hubertus will be

\footnotetext{
$20 \quad$ Hubertus, para. 45.

21 Ibid., para. 55, with reference to para. 29 where the CJEU came to a similar conclusion with respect to Article 2(2) of Directive 2000/78.

22 Ibid., paras. 56-57.

23 Ibid., para. 54.

24 https://ec.europa.eu/eurostat/statistics-explained/index.php/People_in_the_EU_-_population_projections (accessed 18 April 2019).

25 European Commission, An Agenda for Adequate, Safe and Sustainable Pensions, White Paper $\operatorname{COM}(2012) 55$ final, 10-11.
} 
invoked more frequently. Moreover, in light of the EU's policies, the measure could be ideal to bridge the gap between pensionable age and life expectancy.

In Hubertus, the CJEU opened the possibility of unlimited postponement to retirement. We wonder, if the postponement, for example, were to last five or ten years, what is the difference between Hubertus and Mangold? In Mangold, the CJEU was clear that a measure that allows for unlimited successive fixedterm contracts on the grounds of age would deprive workers for a substantial part of their working life from the security that indefinite-term contracts offer. $^{26}$

Our second argument relates to the importance the CJEU contributes to the fact that an employee has access to an alternative source of income, specifically, a retirement pension. This brings retirement-age workers in a different position than younger employees. Nonetheless this argument of the CJEU is rather one dimensional. It ignores the fact that a "job is not only an activity that provides for the worker's needs-it is also a means of social inclusion and recognition." ${ }^{27}$ This is of relevance, because in Article 25 of the Charter of Fundamental Rights of the EU, the EU "recognizes and respects the rights of elderly to lead a life of dignity and independence and to participate in social and cultural life." A pension as alternative source of income may support an independent life, but may not sufficiently support dignity of life or guarantee participation in social and cultural life. Work and security in the employmentrelationship may more successfully contribute to this. As the population grows older overall, the group of workers in need of employment security, especially regarding periods of postponing the retirement age, increases as well. Leaving this group of employees without any security about how long they will be able to keep their job would be just as inhumane as it would be for any other (younger) worker. In this light the recognition by the CJEU of the postponement of the retirement age as a fixed-term contract, following on the previous indefinite-term contract, would have granted these employees at least the protection of the fixed-term work directive. This protection would force the employer to be more clear about why and for how long the retirement age will be postponed, giving employees more employment security, which puts them in a better position to age with dignity.

\footnotetext{
$26 \quad$ Mangold, paras. 64-65.

27 Ch. Degryse, "Shaping the world of work in the digital economy," Foresight Brief(ETUI \#01 January 2017), 9 .
} 
